\title{
The Role of Indonesian Human Resources in Developing MSMEs Facing the Industrial Revolution 4.0
}

\author{
Maskarto Lucky Nara Rosmadi ${ }^{1}$, Herlina ${ }^{2}$, Endah Widiastuti K. ${ }^{3}$, Zaenudin Tachyan ${ }^{4}$ \\ ${ }^{1234}$ Institute of Economic Science Kridatama Bandung, Indonesia \\ maskartolucky@gmail.com
}

\begin{abstract}
This study aims to determine the role of Indonesian HR in increasing MSMEs facing the 4.0 industrial revolution. The research method used is a qualitative method with an analytical and explorative descriptive approach. From the results of the research conducted, it was found that the quality of human resources in the Dzul Collection bag industry was less supportive for developing the industry due to the low level of education and lack of innovation to produce quality products. To improve the quality of human resources, effective and efficient steps are needed through sharing knowledge and exchanging knowledge among fellow employees and training. Through these activities, it is expected that the development of this industrial business can be realized, especially in the face of free markets and global economic competition.
\end{abstract}

Keywords : Innovation; HR Competence; Organizational Culture.

\section{Introduction}

Business organizations grow and develop not because they have production products that have high competitiveness and are accepted by consumers, but are determined by the quality of the human resources that manage them. Without the support of quality human resources, the amount of capital owned by a business organization will mean nothing. Therefore, the management of business organizations is in desperate need of human resources that are creative, skilled, knowledgeable, mastering technology, competitive advantage, and much-needed experience for the development of the company [1] - [2].

The fourth industrial revolution is the development of the previous revolution with the aim of meeting consumer needs for a quality product. In this generation, especially the manufacturing industry is run by utilizing all digital and electrical information technology (IT), and integrated through the internet where the role of humans is only as a machine operator. For that management business organizations must be able to optimize the quality of human resources in order to have the knowledge and expertise that are in accordance with the needs [3] - [14]. The knowledge and expertise in question is an increase in skills related to information technology and English language skills [15-17].

MSMEs as part of microeconomic businesses based on popular economy are expected to be an effort that can reduce poverty and unemployment in Indonesia. From the description above, the authors are interested in examining more deeply the quality of Indonesia's human resources to develop microeconomic businesses to have competitiveness, especially in the face of the 4.0 industrial revolution. The main problem is the extent to which the role of human resources to develop MSMEs is mainly to improve people's welfare.

\section{Review of Literature}

\subsection{Innovation}

To be able to win business competition in the era of globalization, business organizations must be able to make changes mainly related to the type and quality of 
products. This can be done through innovation so that the products they produce are able to compete with other similar companies [18]. Innovation will succeed if creative ideas can be realized [19]. To realize innovation into creativity that is produced through products, it requires strong human resources that are full of imagination and able to pour them through a work of copyright [20-24].

From the results of research conducted by Nikolaou et al. [25], Nasiripour et al. [26], Sanders et al. [27], and Bal, Bozkurt \& Ertemsir [28] it can be concluded, that innovation develops and can be implemented into a product if supported by human resources who have adequate competence. In addition, the work climate, job description, and employee job satisfaction for the company are also very supportive of the birth of these innovations.

\subsection{HR Competence}

Small and medium micro businesses are the type of business that is most appropriate to be implemented in Indonesia amid an uncertain world economy. With financial capital that is not too large, MSMEs are able to survive and contribute to the growth of the national economy. To develop MSMEs, of course, they must be supported by strong and knowledgeable human resources to improve their competence. To overcome the high cost of education and the uneven distribution of public welfare, one of the efforts to improve the quality of human resources is through the transfer of knowledge [29].

By having adequate competencies, it is expected that human resources in MSMEs have competitive advantages to compete with other competitors who produce the same goods and can improve company performance [30-33]. From the results of research conducted by Ryan et al. [34], Koys [35], Allen et al. [36], and Boselie \& Paauve [37] it can be concluded that the competencies possessed by HR in MSMEs must be well managed and developed by management. This is done in addition to increasing the quality and quantity of production so that they do not intend to move to other companies.

\subsection{Organizational culture}

The work environment and work culture are two activities that cannot be separated from MSME activities to create a comfortable and safe working atmosphere for employees. This is done so that employees can improve the quality of MSME products amid competitive global competition [38]. Changes in the work environment and organizational culture are usually carried out at the initiative of top management of the relevant business organization [39]. Therefore, organizational culture is the most important aspect that must be done by management to achieve success in the future [40], [41]. From the results of a study conducted by Salaheldin [41], Wu [42], Hofstede [43], and Zhang [44] it can be concluded that the organizational culture is important and has a positive and significant impact on organizational development.

\section{Research Methods}

This study uses qualitative methods with analytical and explorative descriptive approaches. The object of research is the bag industry located in Kampung Toge, Mekarmulya Village, Pasirjambu District, Bandung Regency. The type of data used is primary data obtained from key informants, and informants by conducting in-depth interviews with information sources. In conducting surveys, researchers use a personal approach (unstructured questionnaire) to obtain information related to the bag industry 
business. The data analysis technique in this study uses a qualitative descriptive model in the form of data collection, data reduction, data display, and then conclusions are made.

\section{Results and Discussion}

From the results of the research conducted, the data shows that the majority of employees in the Dzul Collection bag industry, both permanent employees and contract employees, can be seen in the following table:

Table 1. Number of Permanent and Non-Permanent Employees Based on Education Level

\begin{tabular}{|c|c|c|c|c|c|c|}
\hline No & $\begin{array}{c}\text { Employee } \\
\text { Status }\end{array}$ & Total & $\begin{array}{c}\text { Senior } \\
\text { High } \\
\text { School }\end{array}$ & $\begin{array}{c}\text { Junior } \\
\text { High } \\
\text { School }\end{array}$ & $\begin{array}{c}\text { Elementary } \\
\text { School }\end{array}$ & \multicolumn{1}{|c|}{ Description } \\
\hline 1 & $\begin{array}{c}\text { Permanent } \\
\text { employmen } \\
\text { t contract }\end{array}$ & 14 & 2 & 5 & 9 & $\begin{array}{l}\text { Non-permanent employees are used if } \\
\text { there is an increase in the number of } \\
\text { orders with a specific target that cannot } \\
\text { be completed by permanent employees. }\end{array}$ \\
\hline 2 & $\begin{array}{c}\text { Temporary } \\
\text { contracts }\end{array}$ & $\begin{array}{c}30-50 \\
\text { People }\end{array}$ & - & - & - & $\begin{array}{l}\text { For temporary employes, the level of } \\
\text { education is varied and some even drop } \\
\text { out of school at the elementary school } \\
\text { level }\end{array}$ \\
\hline
\end{tabular}

From table 1 above, it can be explained that the human resources possessed by Dhul Collection, both permanent and non-permanent employees, have inadequate education. This is certainly an obstacle for management to improve production and organizational development in general. Therefore, in the face of industrial revolution 4.0, the implementation of work that mostly utilizes information technology can certainly have an impact on the reduced use of human resources, especially those who do not have the competence to face business competition in the global era. This was revealed by Vaidya et al. [3], Pasban \& Nojedeh [4], and Garavan et al. [5] which states that in the face of the industrial revolution 4.0 business organizations must have human resources capable of supporting the development of companies by mastering information technology especially to improve the quality of production.

Owner Dhul Collection realizes that employees who work in his company have many shortcomings. To anticipate that the organization he leads continues to move and develop in meeting market needs, the owner strives to create a comfortable working atmosphere and employees can exchange knowledge and experience so that their limited education can be covered by skills and expertise in producing the highest quality bags. This was stated by Flynn and Saladin [40] that business organizations will grow and develop if top management pays attention to the organizational culture within the company.

With the creation of a comfortable and safe working atmosphere, it is expected that the productivity and performance of the organization and employees can increase. In addition, competitiveness in terms of quality and quantity in the form of innovation and creativity of products produced especially with similar companies can bring a positive impact on organizational development and employee welfare. Therefore the development of business organizations will be realized not only supported by human resources who have adequate education, but more than that there is a synergy between fellow employees and employees with management to produce products that can be accepted by consumers and markets in general. 


\section{Conclusion}

From the description above, it can be seen that the factors for developing MSMEs are not only sourced from quality human resources but also must be supported by other factors such as employee innovation and creativity to produce quality products that are acceptable to consumers. The limited level of education possessed by the Dhul Collection bag industry HR is not a major obstacle. This can be addressed by exchanging knowledge, sharing knowledge and supported by organizational management that can manage employee performance through the application of organizational culture and a good work culture.

\section{References}

[1] Lutz Hendricks, "How Important is Human Capital for Development? Evidence from Immigrant Earnings," American Economic Review, vol. 92, no. 1, pp. 198-219, 2002.

[2] Carla Haelermans and Lex Borghans, "Wage Effects of On-the-Job Training: A MetaAnalysis," BJIR-An International Journal of Employmnet Relations, vol. 50, no. 3, pp. 502-528, September 2012.

[3] Saurabh Vaidya, Prashant Ambad, and Santosh Bhosle, "Industry 4.0-AGlimpe," Procedia Manufacturing, vol. 20, pp. 233-238, January 2018.

[4] Mohammad Pasban and Sadagheh Hosseinzadeh Nojedeh, "A Review of the Role of Human Capital in the Organization," in 3rd International Conference on New Challenges in Management and Organization: Organization and Leadership, vol. 230, Dubai, UAE, 2016, pp. 249-253.

[5] Thomas N. Garavan, Michael Morley, Patrick Gunnigle, and Eammon Collins, "Human Capital Accumulation: the Role of Human Resource Development," Journal of European Industrial Training, vol. 25, no. 2/3/4, pp. 48-68, 2001.

[6] Karthik Namasivayam and Basak Denizci, "Human Capital in Service Organizations: Identifying Value Drivers," Journal of Intellectual Capital, vol. 7, no. 3, pp. 381-393, 2006.

[7] Ki Seok Jeon and Kyung-Nyun Kim, "How do Organizational and Task Factors Influence Informal Learning in the Workplace?," Human Resource Development International, vol. 15, no. 2, pp. 209-226, April 2012.

[8] Timothy F. Bresnahan, Erik Brynjolfsson, and Lorin M. Hitt, "Information Technology, Workplace Organization, and the Demand for Skilled Labor: Firm-Level Evidence," The Quarterly Journal of Economics, vol. 117, no. 1, pp. 339-376, February 2002.

[9] Iaus Dieter Thoben, Stefan Alexander Wiesner, and Thorsten Wuest, "Industrie 4.0 and Smart Manufacturing-A Review of Research Issues and Application Examples," International Journal of Automation Technology, vol. 11, no. 1, pp. 4-19, January 2017.

[10] Konstantinos Sipsas, Kosmas Alexopoulos, Vangelis Xanthakis, and George Chryssolouris, "Collaborative maintenance in Flow-line Manufacturing Environments: An Industry 4.0 Approach," ScienceDirect-Procedia CIRP, vol. 55, pp. 236-241, 2016.

[11] Frank Rennung, Caius Tudor Luminosu, and Anca Draghici, "Service Provision in the Framework of Industry 4.0," Procedia-Social and Behavioural Sciences, vol. 221, pp. 372-377, 2016. 
[12] Malte Brettel, Niklas Friederichsen, Michael Keller, and Marius Rosenberg, "How Virtualization, Decentralization and Network Building Change the Manufacturing Landscape: An Industry 4.0 Perspective," International Journal of Mechanical, Aerospace, Industrial, Mechatronic and Manufacturing Engineering, vol. 8, no. 1, pp. 37-44, 2014.

[13] Reimund Neugebauer, Sophie Hippmann, Miriam Leis, and Martin Landherr, "Industrie 4.0- Form the Perspective of Apllied Research," Procedia CIRP, vol. 57, pp. 2-7, December 2016.

[14] Jian Qin, Ying Liu, and Roger Grosvenor, "A Categorical Framework of Manufacturing for Industry 4.0 and Beyond," Procedia CIRP, vol. 52, pp. 173-178, 2016.

[15] Madrak Grochawska Malgorzata, "The Knowledge-based Economy as a Stage in the Development of the Economy," Oeconomia Copernicana, vol. 6, no. 2, pp. 7-21, 2015.

[16] Wioletta Wierzbicka, "Information Infrastructure as a Pillar of the Knowledge-based Economy-An Analysis of Regional Differentiation in Poland," Equilibrium. Quarterly Journal of Economics and Economic Policy, vol. 13, no. 1, pp. 123-139, 2018.

[17] Yulia V. Ragulina, Elena I. Semenova, Irina A. Zueva, Elena V. Kletskova, and Elena N. Belkina, "Perspectives of solving the problems of regional development with the help of new internet technologies," The International Journal Entrepreneurship and Sustainability Issues, vol. 5, no. 4, pp. 890-898, 2018.

[18] Ika Nurul Qamari, Retno Widowati PA., Fauziah, and Femi Kurnia, "The Use of Communication and Information Technology Innovation Among Micro, Small and Medium Enterprises," International Journal of Scientific Research and Management (IJSRM), vol. 0, no. 11, pp. 320-326, 2018.

[19] Doris Fay, Helen Shipton, Michael A. West, and Malcolm Patterson, "Teamwork and organizational innovation: The moderating role of the HRM context," Creativity and Innovation Management, vol. 24, no. 2, pp. 261-277, 2015.

[20] Salih Yesil, Alaeddin Koska, and Tuba Buyukbese, "Knowledge Sharing Process, Innovation Capability and Innovation Performance: An Empirical Study," ProcediaSoscial and Behavioral Sciences, vol. 75, pp. 217-225, 2013.

[21] Karen L. Becker and Judy H. Matthews, "Linking HRM and innovation: formulating the research agenda," in 22nd ANZAM Conference 2008: Managing in the Pasific Century, Auckland, New Zealand, 2008.

[22] Michael D. Mumford, "Managing Creative People: Strategies and Tactics for Innovation," Human Resource Management Review, vol. 10, no. 3, pp. 313-351, 2000.

[23] Kaifeng Jiang, David P. Lepak, Jia Hu, and Judith C. Baer, "How Does Human Resource Management Influence Organizational Outcomes? A Meta Analytic Investigation of Mediating Mechanisms," Academy of Management Journal, vol. 55, no. 6, pp. 12641294, 2012.

[24] Mine Afacan Findikli, Ugur Yozgat, and Yasin Rofcanin, "Examining Organizational Innovation and Knowledge Management Capacity, The Central Role of Strategic Human Resources Practices (SHRPs)," Procedia-Social and Behavioral Science, vol. 181, pp. 377-387, 2015.

[25] Ioannis Nikolaou, Maria Vakola, and Dimitris Bourantas, "Who speaks up at work? 
Dispositional influences on employees' voice behavior," Personnel Review, vol. 37, no. 6, pp. 666-679, 2008.

[26] A.A. Nasiripour, A. Radfar, and M. Badpa, "Assessment of Knowledge-Sharing Role in Innovation (Case Study: Isfahan R\&D Scientific Small City)," International Journal of Academics and Management Sciences, vol. 2, no. 6, pp. 150-157, 2013.

[27] Karin Sanders, Matthijs Moorkamp, Nicola Torka, Sandra Groeneveld, and Claudia Groeneveld, "How to Support Innovative Behaviour? The Role of LMX and Satisfaction with HR Practices," Technology and Investment, vol. 1, pp. 59-68, 2010.

[28] Yasemin Bal, Serdar Bozkurt, and Esin Ertemsir, "A study on determining the relationship between strategic HRM practices and innovation in organizations," in Management, Knowledgeand Learning International Conference, Zadar-Croatia, 2013.

[29] Bisma Mannan, Sonal Khurana, and Abid Haleem, "Knowledge Management as an Enabler of Innovation Management in India MSMEs," in International Conference and Exibition on Building Utilities 2016, New Delhi, India, 2016, pp. 357-364.

[30] Patrick M. Wright, Gary C. McMahan, Blaine McCormick, and W. Scott Sherman, "Strategic, core competence, and HR involvement as determinants of HR effectiveness and refinery performance," Journal of Human Resource Management, vol. 37, no. 1, pp. 17-29, 1998.

[31] Aron O'Cass and Liem Viet Ngo, "Winning through innovation and marketing: lesson from aurstralia and vietnam," Industrial Marketing Management, vol. 40, no. 8, pp. 1319-1329, 2011.

[32] Scott B. Parry, "Just what is a competency? (And Why Should You Care?)," Journal of Training, vol. 35, no. 6, pp. 58-60, 62,64, 1996.

[33] Jay Barney, "Firm resources and sustained competitive advantage," Journal of Management, vol. 17, no. 1, pp. 99-120, 1991.

[34] Ann Marie Ryan, Mark J. Schmit, and Raymond Johnson, "Attitudes and effectiveness: Examining relations at an organizational level," Personnel Psychology, vol. 49, no. 4, pp. 853-882, 1996.

[35] Daniel J. Koys, "The effects of employee satisfaction, organizational citizenship behavior and turnover on organizational effectiveness: A unit-level, longitudinal study," Personnel Psychology, vol. 54, no. 1, pp. 101-114, 2001.

[36] David G. Allen, Lynn M. Shore, and Rodger W. Griffeth, "The role of perceived organizational support and supportive human resource practices in the turnover process," Journal of Management, vol. 29, no. 1, pp. 99-118, 2003.

[37] Jean Paul Boselie and Jaap Paauve, "'Human resource function competencies in European companies," Personnel Review, vol. 34, no. 5, pp. 550-566, 2005.

[38] Shahab Alam Malik, Muhammad Zahid Iqbal, Razia Shaukat, and Jia Young, "TQM Practices and Organizational Performance: Evidence from Pakistani SMEs," International Journal of Engineering and Technology, vol. 10, no. 4, pp. 26-31, 2010.

[39] Kim S. Cameroon and Robert E. Quinn, Diagnosing and Changing Organizational CultureBased on the Competing Values Framework, Revised ed. USA: John Wiley \& Sons, 2006.

[40] Barbara B. Flynn and Broke Saladin, "Relevance of Baldrige constructs in an international context: A study of national culture," Academy of Management Annual Meeting Proceedings, vol. 24, no. 5, pp. 583-603, 2006. 
[41] Ismail Salaheldin Salaheldin, "Critical success factors for TQM implementation and their impact on performance of SMEs," International Journal of Productivity and Performance Management, vol. 58, no. 3, pp. 215-237, 2009.

[42] Ming-Yi Wu, "Hofstede's Cultural Dimensions 30 Years Later: A Study of Taiwan and the United States," Intercultural Communication Studies, vol. XV, no. 1, pp. 33-42, 2006.

[43] Zhihai Zhang, "Developing a model of quality management methods and evaluating their effects on business performance," Total Quality Management, vol. 11, no. 1, pp. 129-137, 2006.

[44] Geert H. Hofstede, Culture Consequences: Comparing Values, Behaviors, Institutions and Organizations Actions nations, 2nd ed. California, USA: Sage, 2001. 